Comparación entre el uso de dos derechos de acceso pesquero, concesiones y permisos, en la pesquería de erizo rojo de mar, Strongylocentrotus franciscanus (Agassiz), en Santo Tomás, Baja California, México

\title{
Modelling the use of two fishery access rights, concessions and licences, in the red sea urchin, Strongylocentrotus franciscanus (Agassiz), fishery at Santo Tomás, Baja California, Mexico
}

\author{
Evlin Ramírez-Félix ${ }^{1}$ \\ Héctor G. Manzo-Monroy² \\ ${ }^{1}$ Dirección General de Investigación Pesquera en el Pacífico Norte \\ Instituto Nacional de la Pesca \\ Apartado postal 1177 \\ Mazatlán, CP 82010, Sinaloa, México \\ E-mail: evlinr@yahoo.com.mx \\ ${ }^{2}$ Facultad de Ciencias Marinas \\ Universidad Autónoma de Baja California \\ Apartado postal 453 \\ Ensenada, CP 22800, Baja California, México
}

Recibido en junio de 2003; aceptado en mayo de 2004

\section{Resumen}

Se simularon diversos escenarios pesqueros con situaciones de riesgo para la pesquería del erizo rojo de mar, Strongylocentrotus franciscanus, y se evaluó el efecto de dos tipos de derechos de uso en la legislación pesquera mexicana: permisos y concesiones. La biomasa del recurso se calculó con dos modelos, el de depensación crítica y el de Schaefer, tanto dinámica como estáticamente. Los parámetros requeridos por cada modelo se determinaron por dos vías: información de oficinas gubernamentales y generando números estocásticos por el Método Monte Carlo ajustándose a un modelo dinámico. El ajuste de los valores de los parámetros de ambos modelos fue por medio de generación de números estocásticos por el méodo de Monte Carlo. En general, ambos modelos pronosticaron capturas menores a las obsevadas. En las simulaciones hechas para cinco años con ambos modelos para el sistema de permisos la biomasa disminuye y con concesiones se mantiene al alza con excepción de los años con temperaturas altas, por lo que la mejor opción para preservar la pesquería es otorgar concesiones en comparación con permisos.

Palabras clave: erizo rojo de mar, efecto Allee, depensación crítica, Schaefer, Bayes, concesión, permiso.

\begin{abstract}
Various stages of the red sea urchin, Strongylocentrotus franciscanus (Agassiz), fishery were simulated to evaluate the effect of two types of access rights under Mexican law: concessions and licences. The resource biomass was evaluated using the critical depensation and Schaefer models. Each model was evaluated as a static or dynamic system. The parameters required for each model were determined from government data and by generating stochastic numbers using the Monte Carlo method to adjust to a dynamic model. In general, both models predicted catches smaller than those observed. The five-year-period simulation for both models showed a drop in biomass when licences are issued, whereas a similar simulation for concessions resulted in increased biomass, except when high temperatures occurred. Our results suggest that issuing concessions rather than licences is the best option to conserve the fishery.
\end{abstract}

Key words: red sea urchin, Allee effect, critical depensation, Schaefer, Bayes, concessions, licences.

\section{Introducción}

El erizo rojo de mar, Strongylocentrotus franciscanus (Agassiz), se distribuye geográficamente desde Alaska, EUA, hasta Isla Cedros, Baja California (BC), México (Mottet, 1976). Su extracción en Baja California inició en la década de

\section{Introduction}

The red sea urchin, Strongylocentrotus franciscanus (Agassiz), is distributed from Alaska, USA, to Cedros Island, Baja California, Mexico (Mottet, 1976). This species has been harvested since 1960 in Baja California (Malagrino-Lumare, 
1960 (Malagrino-Lumare, 1972). A partir de los años setenta se otorgaron permisos para su explotación comercial y, hacia fines de 1994, aparecieron publicadas en el Diario Oficial de la Federación (DOF, 23 de diciembre de 1994) concesiones pesqueras del recurso. Las capturas (en peso entero) de erizo en Baja California han presentado grandes fluctuaciones con máximos en 1979 (5700 t) y 1986 (8500 t), y capturas mínimas en 1981 y 1983 (de 986 y 929 t respectivamente). De 1987 a 2001, de acuerdo a la Carta Nacional Pesquera, la producción ha oscilado entre 1000 y 5500 t (DOF, 15 de marzo, 2004). A partir de 1993 se estableció la época de veda en Baja California del 1ro. de marzo al 30 de junio de cada año (DOF, 18 de octubre de 1993).

Los equinodermos son animales exclusivamente marinos. Todos los miembros de este filo son dióicos y su fecundación es externa (Barnes, 1977). Comúnmente se localizan en mantos de macroalgas (Macrocystis pyrifera) por ser éstas su alimento preferido, aunque también pueden habitar sustratos rocosos (Palleiro, 1987) a profundidades entre diez a treinta metros (o mayores) (Mottet, 1976) creciendo hasta un diámetro de testa cercano a $18 \mathrm{~cm}$ (Palleiro, 1982).

Las medidas administrativas comúnmente empleadas en la pesquería del erizo en algunos países como México y Estados Unidos incluyen límite de talla, cierres temporales/área y acceso limitado (Haaker, 1992; Halman y Rudie, 1992; Botsford et al., 1993; Botsford y Quinn, 1994), pero estas varían de país a país. Con la finalidad de promover la conservación de las poblaciones de invertebrados, los administradores han definido como componentes de su conservación los siguientes: protección del potencial reproductivo, control del esfuerzo e incremento del reclutamiento y sobrevivencia (Jamieson y Caddy, 1986).

Existen dos tipos de derechos de uso comercial de recursos pesqueros en la legislación mexicana: permisos y concesiones (Ley de Pesca y su Reglamento, 1999). La diferencia entre permisos y concesiones es la temporalidad de los derechos. La concesión requiere del solicitante cumplir con un mayor número de requistos como (1) un estudio económico, (2) la solicitud debe explicar qué se va a hacer con el recurso, (3) deberá indicar cuál será la inversión y su tasa de recuperación y (4) deberá demostrar la propiedad o disposición legal de las artes de pesca y embarcaciones (redes, barcos) requeridas. Los permisos solamente requieren los números 2 y 4 (Ley de Pesca y su Reglamento, 1999) y, mientras que éstos tienen una duración de hasta 4 años, las concesiones pueden durar hasta 50 años. Por ello, es menos frecuente que se solicite una concesión que un permiso. Las concesiones se otorgan regularmente para recursos bentónicos y en una área definida geográficamente.

Con una concesión el poseedor asegura la explotación de una zona adquieriendo cierto sentido de propiedad de la misma, lo que le brinda una mayor seguridad al invertir e incentiva en él la protección y el uso eficiente del recurso. En cambio, al caducar la vigencia del permiso de extracción su poseedor no tiene ninguna seguridad de que éste se renueve, lo
1972). Commercial licences have been issued since the 1970 s and, according to the Diario Oficial de la Federación (DOF, 23 December 1994), at the end of 1994 fishery concessions of this resource were granted. Sea urchin landings (in total weight) in Baja California peaked in 1979 (5700 t) and 1986 (8500 t), but were minimal in 1981 and 1983 (986 t and $929 \mathrm{t}$, respectively). From 1987 to 2001, landings varied between 1000 and $5500 \mathrm{t}$ (National Fishery Charter, DOF, 15 March 2004). In 1993, a closed season was established in Baja California from 1 March to 30 June (DOF, 18 October 1993).

The Echinodermata are exclusively marine. All members of the phylum are dioicous and feature external fecundation (Barnes, 1977). They are commonly found in kelp (Macrocystis pyrifera) forests since this is their favorite food, but they can also inhabit rocky bottoms (Palleiro, 1987) between 10 and $30 \mathrm{~m}$ (or more) depth (Mottet, 1976), growing to a diameter of $18 \mathrm{~cm}$ (Palleiro, 1982).

Current management strategies for the sea urchin fishery include limited entry, size limits and a closed season (Haaker, 1992; Halman and Rudie, 1992; Botsford et al., 1993; Botsford and Quinn, 1994), but these vary in different countries. To conserve stocks, three conservation strategy components have been defined: protect the spawning potential, control the fishing effort and increase juvenile recruitment and survival (Jamieson and Caddy, 1986).

Mexican law contemplates two types of commercial rights for fishery resources: licences and concessions (Ley de Pesca y su Reglamento, 1999). The difference between licences and concessions is the duration of the rights, the former valid for up to 4 years, whereas the latter can last 50 years. To obtain a concession rather than a licence the applicant must comply with a greater number of requirements: (1) an economic feasibility study, (2) explain how the resource will be used, (3) specify the amount of the investment and return, and (4) prove the legal ownership or availability of the fishing gear required (ships, nets). To obtain a licence, only (2) and (4) must be fulfilled. Consequently, concessions are less frequently granted than licences and are generally issued for benthic resources within a defined area.

The concession holder is assured the exploitation of an area and acquires some sense of property and security, with the incentive to protect and efficiently use the resource. On the other hand, licence holders are not guaranteed their renewal on expiry and this often leads to the inefficient use or abuse of the resource. This concept is known as the value of a resource in time, which in the case of concessions lies in the future (long term) and in the case of licences lies in the present (short term). 
que puede traer consigo un uso ineficente o abuso del recurso. Esto se conoce también como el valor del recurso en el tiempo que, para el caso de las concesiones es a futuro (largo plazo) y para los permisos vale más en el presente (corto plazo).

$\mathrm{El}$ aprovechamiento del erizo rojo en México se regula con la Norma Oficial Mexicana (NOM) 007-PESC-1993, misma que establece una talla mínima de $8 \mathrm{~cm}$ de diámetro de caparazón, el uso de una embarcación menor de hasta 7.3 metros (24 pies) de eslora con motor fuera de borda equipada con compresor para buceo semi autónomo, y con una tripulación que no exceda de tres personas (DOF, 16 de diciembre de 1993). Además, la extracción del erizo será únicamente mediante buceo semiautónomo y los organismos deberán entregarse enteros a las plantas de procesamiento, entre otras reglas. Por su parte, la Carta Nacional Pesquera estipula que no se deberán otorgar nuevas concesiones además de disminuír el esfuerzo de pesca hasta que la pesquería muestre signos de recuperación (DOF, 15 de marzo, 2004).

Entre los modelos más sencillos usados en pesquerías se encuentran los de dinámica de biomasa, que requieren pocos parámetros y variables observadas. En los modelos de producción pesquera comúnmente se emplea una función de producción biológica de tipo compensatoria, sin embargo, para organismos bentónicos y de poca movilidad se ha propuesto la existencia de mortalidad de tipo depensatoria y el efecto Allee. Los adultos ofrecen un refugio parcial a los juveniles (Tegner y Dayton, 1981), lo cual indica que el reclutamiento es densodependiente con un gran asentamiento en áreas donde existe un gran número de adultos (Baker, 1973). Al dispersarse las larvas existen dos posibles causas del efecto Allee en su reclutamiento: la eficiencia de fertilización disminuye con densidades bajas de desovantes (Levitan, 1991; citado por Botsford y Quinn, 1994); y el grado de protección de nuevos reclutas bajo las espinas de los adultos también disminuye cuando éstos presentan menor densidad (Tegner y Dayton, 1977, citado por Botsford y Quinn, 1994). Ambos factores hacen a la especie muy susceptible a la sobrepesca (Botsford y Quinn, 1994).

La relación depensatoria en la función de crecimiento poblacional puede ser causada tanto por una relación depredador-presa como por una disminución en el éxito de la fertilización en densidades muy bajas de organismos adultos (efecto Allee). Estos dos mecanismos pueden actuar simultáneamente, o aún más, reforzarse. Neave (1953) fue el primero en utilizar el término depensación y propuso tres tipos de mortalidad: (1) compensatoria, cuando la población tiende a equilibrarse en un nivel de capacidad de carga; (2) depensatoria, cuando la mortalidad tiende a ser muy alta conforme la densidad de población disminuye; y (3) extrapensatoria, la mortalidad es densoindependiente.

La depredación total se ve afectada por dos variables esenciales, la densidad de la presa y la del depredador. Las características principales de la depredación pueden entenderse por los cambios dinámicos de ambas variables. La respuesta funcional se define como el incremento en el número de presas consumidas por depredador, conforme la densidad de la presa
The extraction of the red sea urchin in Mexico is controlled by the Official Mexican Norm (NOM) 007-PESC-1993, which establishes $8 \mathrm{~cm}$ as minimal carapace diameter, the use of a boat not longer than 7.3 meters ( 24 feet) with outboard engine and Hooka diving compressor, and a crew of not more than three persons (DOF, 16 December 1993). The extraction of sea urchin must be by Hooka diving and specimens should be delivered whole to the processing plants. Furthermore, the National Fishery Charter stipulates that new concessions should not be granted and recommends reducing the fishing effort until the fishery shows some eividence of recovery (DOF, 15 March 2004).

The simplest fishery models are those that consider only a single indicator of population size, usually biomass. These methods are related to dynamic biomass, requiring few parameters and observed variables. In fishery production models it is common to use a biological production function of compensatory type. For benthic organisms with low mobility, however, the concurrence of depensatory mortality and the Allee effect has been suggested. Adults give partial shelter to juveniles (Tegner and Dayton, 1981), showing that recruitment is density-dependent with greater settlement in areas where there are a large number of adults (Baker, 1973). When larvae are dispersed, there are two potential Allee effects in recruitment: the efficiency of fertilization declines with low spawning stock density (Levitan, 1991, in Botsford and Quinn, 1994), and the protection of new recruits decreases because of the low density of adult canopy spines (Tegner and Dayton, 1977, in Botsford and Quinn, 1994). Both factors make red sea urchins particularly sensitive to over- fishing (Botsford and Quinn, 1994).

The depensatory relationship in the population growth function may be caused by either a predator-prey relationship or a decrease in the fertilization success at very low densities of adult organisms (Allee effect). These two mechanisms may act together or they may reinforce one another. Neave (1953) first used the term depensation and proposed three types of mortality: (1) compensatory, when the population tends to stabilize at a certain level (carrying capacity); (2) depensatory, when mortality tends to be higher as the population density decreases; and (3) extrapensatory, when mortality is densityindependent.

Total predation is affected by two essential variables: the density of the prey and that of the predator. The basic features of predation can be explained by the dynamic changes of these two variables. The functional response is defined as the increase in the number of prey consumed per predator as prey density rises, while the change in the density of predators is 
se incrementa. El cambio en la densidad del depredador se denomina respuesta numérica (Solomon, 1949 citado por Holling, 1959).

Ricker (1954) identificó que el proceso de mortalidad depensatoria puede resultar de que la línea de reemplazo cruce la curva de reproducción (reclutamiento) en dos o tres puntos, lo cual da origen a más de un punto de equilibrio de la población. Si la curva de crecimiento cruza la línea de reemplazo por abajo existe un equilibrio inestable y el tamaño de la población tiende a cambiar hasta otro punto de equilibrio estable, el cual se alcanza cuando la curva de crecimiento cruza la de reemplazo por arriba. Éstos son los llamados dominios de atracción de la población (Peterman, 1977).

El presente trabajo evalúa los efectos de una concesión pesquera, en comparación con los de un permiso de extracción, en la pesquería de erizo del área de Santo Tomás a Punta China, Baja California (México), y calcula la biomasa por medio de los modelos de depensación crítica y de Schaefer.

\section{Materiales y métodos}

El área de estudio comprendió de Punta Santo Tomás a Punta China, BC, México, a aproximadamente $55 \mathrm{~km}$ al sur del Puerto de Ensenada. Es una zona protegida de la acción de las corrientes y el oleaje, con grandes zonas con fondo arenoso pero con una franja rocosa de bajo relieve y con mantos de algas cafés, Macrocystis pyrifera (Agardh), que dependiendo de las condiciones ambientales pueden cubrir gran parte del área (Romero y Bertsch, 1984).

Los parámetros se calcularon para el período de 19831994, sin embargo, la información para estimarlos se obtuvo de diferentes fuentes para distintos períodos. Para el periodo de 1983-1987 se obtuvo con base en la contribución porcentual de la zona a la captura estatal, para el de 1988-1992 de Palleiro et al. (1994), y para el de 1993-1994 de la Subdelegación Federal de Pesca en Baja California. El coeficiente de capturabilidad $(q)$ se obtuvo con los datos de biomasa determinados para la zona por Palleiro (1982).

Para describir el comportamiento de la biomasa poblacional en el tiempo y predecir las capturas con el modelo de producción de Schaefer y de depensación crítica tanto estática como dinámicamente, se determinaron los parámetros para cada uno de los modelos: tamaño de la población en equilibrio natural $(k)$, biomasa de la población capturable $(B)$, tasa intrínseca de crecimiento poblacional $(r)$, coeficiente de capturabilidad $(q)$ y población crítica $\left(k_{o}\right)$. El modelo de Schaefer no utiliza este último parámetro.

Para determinar los parámetros poblacionales se generaron números estocásticos por el Método Monte Carlo (Sóbol, 1983). El rango de cada uno de ellos fue $r=0.3-1.1$, $k=1800-5500 \mathrm{t}, \quad B=1300-3000 t, \quad k_{o}=65-200 \mathrm{t}, \mathrm{y} \quad q=$ $7 \times 10^{-5}-1.4 \times 10^{-4}$, y por medio de un ajuste de mínimos cuadrados se determinó el valor óptimo de cada parámetro, al que se le denominó parámetro base. termed numerical response (Solomon, 1949, cited in Holling, 1959).

Ricker (1954) noted that depensatory mortality processes might result from the replacement line crossing the recruitment curve at two or three points, yielding more than one equilibrium point. If the reproduction (recruitment) curve crosses the replacement line from below there is an unstable equilibrium and the population increases or decreases until another stable equilibrium is reached, when the reproduction (recruitment) curve crosses the replacement line from above. These are named population domains of attraction (Peterman, 1977).

This work assesses the effects of implementing concessions against issuing extraction licences on the red sea urchin fishery from Santo Tomás to Punta China, Baja California (Mexico), and estimates the resource's biomass using the Schaefer and critical depensation models.

\section{Materials and methods}

The study area extended from Santo Tomás to Punta China, Baja California (Mexico), about $55 \mathrm{~km}$ south of Ensenada. The area is protected from the current and wave action and has an extensive sandy bottom. It has rocky edges with beds of brown alga, Macrocystis pyrifera (Agardh), that can cover a large part of the area depending on the weather conditions (Romero and Bertsch, 1984).

Parameters were calculated for the 1983-2004 period. The information was obtained from different sources for different periods: for 1983-1987 from the percent contribution of the zone to the state catch, for 1988-1992 from Palleiro et al. (1994), and for 1993-1994 from data provided by the Subdelegación Federal de Pesca in Baja California. The catchability coefficient $(q)$ was determined with the biomass data determined for the area by Palleiro (1982).

To describe and predict the population biomass behavior over time using the Schaefer production model and the critical depensation model, both statically and dynamically, the parameters were determined for each model: carrying capacity $(k)$, catchable stock biomass $(B)$, intrinsic rate of population increase $(r)$, catchability coefficient $(q)$, and critical population $\left(k_{o}\right)$. The Schaefer model does not use this last parameter.

To determine the population parameters, stochastic numbers were generated using the Monte Carlo method (Sóbol, 1983). The range for each of them was $r=0.3-1.1, k=1800$ $5500 \mathrm{t}, B=1300-3000 \mathrm{t}, k_{o}=65-200 \mathrm{t}$, and $q=7 \times 10^{-5}-1.4 \times$ $10^{-4}$, and the optimum value of each parameter was determined by a least squares fit and called the basic parameter. 
Para el modelo estático de Schaefer (Hilborn y Walters, 1992):

$$
Y=q k[1-q / r E]=q k E-k q^{2} / r E^{2}=a E-b E^{2}
$$

donde $Y$ es la captura en equilibrio ó la producción sustentable que le corresponde al esfuerzo $E, k$ es la capacidad de carga, $r$ la tasa intrínseca de crecimiento pobacional, $q$ el coeficiente de capturabilidad, $a$ el intercepto y $b$ la pendiente.

Para el modelo estático de depensación crítica (Clark, 1976) la biomasa en equilibrio estático está dada por:
To predict the static Schaefer model (Hilborn and Walters, 1992):

$$
Y=q k[1-q / r E]=q k E-k q^{2} / r E^{2}=a E-b E^{2}
$$

where $Y$ is the equilibrium catch or the sustainable production that corresponds to effort $E, k$ is the carrying capacity, $r$ is the intrinsic rate of population increase, $q$ is the catchability coefficient, $a$ is the intercept and $b$ is the slope.

To predict the static depensation model (Clark, 1976), the biomass is in static equilibrium and equal to

$$
x(e s f)=\frac{-q E+r(1+k o / k) \pm \sqrt{(q E-r(1+k o / k))^{2}-4(r / k)(r k o)}}{2 r / k}
$$

Para el modelo dinámico de Schaefer (Hilborn y Walters, 1992) tenemos:

$$
x_{\mathrm{t}+1}=x_{\mathrm{t}}+r x_{\mathrm{t}}\left[1-x_{\mathrm{t}} / k\right]-c_{\mathrm{t}}
$$

donde $c_{\mathrm{t}}$ es la captura observada en el tiempo $t, x_{\mathrm{t}}$ es la biomasa en el tiempo $t$ y $x_{\mathrm{t}+1}$ es la biomasa en el tiempo $t+1$.

La captura calculada es

$$
\hat{C}_{\mathrm{t}}=q x_{\mathrm{t}} E_{\mathrm{t}}
$$

donde $\hat{C}_{\mathrm{t}}$ es la captura calculada y $E_{\mathrm{t}}$ el esfuerzo observado en el tiempo $t$.

Para el modelo dinámico de depensación la biomasa es

$$
x_{\mathrm{t}+1}=x_{\mathrm{t}}+r\left(x_{\mathrm{t}}-k_{0}\right)\left(1-x_{\mathrm{t}} / k\right)-c_{\mathrm{t}}
$$

La captura calculada en el tiempo es $\hat{c}_{\mathrm{t}}=q x_{\mathrm{t}} E_{\mathrm{t}}$.

Para predecir la biomasa y captura con eventos riesgosos se utilizó la probabilidad de Bayes en situación de explotación pesquera con permisos y concesiones sólo con los parámetros base.

Para determinar los riesgos asociados se realizaron encuestas entre los actores involucrados en la pesquería incluyendo permisionarios, industriales, buzos y administradores. A partir de ello se definieron posibles escenarios con relación a los porcentajes de pesca furtiva, riesgo de cambio de zona al renovar permisos y ocurrencia de temperaturas anómalas (fig. 1). Sobre la cuota de captura previamente establecida se definieron dos porcentajes de pesca furtiva, 30\% y 10\%, y para ambos casos tres posibles intervalos de temperatura (alta, baja y normal). Con relación al comportamiento de los permisionarios se consideraron dos alternativas, que el permisionario capture $30 \%$ más de la cuota de captura establecida ( $P$ en la fig. 1) o que respete y ejerza únicamente su cuota de captura (I en la fig. 1). La combinación de estas alternativas da un total de doce posibiles escenarios para cada modelo (fig. 1). De estos posibles
To predict the dynamic Schaefer model (Hilborn and Walters, 1992):

$$
x_{\mathrm{t}+1}=x_{\mathrm{t}}+r x_{\mathrm{t}}\left[1-x_{\mathrm{t}} / k\right]-c_{\mathrm{t}}
$$

where $c_{\mathrm{t}}$ is the observed catch at time $t, x_{\mathrm{t}}$ is the biomass at time $t$ and $x_{\mathrm{t}+1}$ is the biomass at time $t+1$.

The estimated catch is

$$
\hat{C}_{\mathrm{t}}=q x_{\mathrm{t}} E_{\mathrm{t}}
$$

where $\hat{C}_{\mathrm{t}}$ is the estimated catch and $E_{\mathrm{t}}$ the observed effort at time $t$.

To predict the dynamic depensation model the biomass is

$$
x_{\mathrm{t}+1}=x_{\mathrm{t}}+r\left(x_{\mathrm{t}}-k_{0}\right)\left(1-x_{\mathrm{t}} / k\right)-c_{\mathrm{t}}
$$

The estimated catch at time $t$ is $\hat{c}_{\mathrm{t}}=q x_{\mathrm{t}} E_{\mathrm{t}}$.

Biomass and catch were predicted by the model taking into consideration risk factors using Bayes' probability with extraction licences and concessions with only the basic parameters.

Licence and concession holders, fishermen, industrialists and management officials were polled to determine the risks associated with the fishery. Based on this information, scenarios were defined related to fishing by poachers, fishing zone reallocation on licence renewal and anomalous water temperature (fig. 1). Two poaching rates over the established quota were used: $30 \%$ and $10 \%$. For each rate we considered three possible temperature ranges (high, low and normal) and for each of those temperatures, two alternative behaviors by the licence and concession holders: one with the licence holder taking $30 \%$ more than the authorized quota ( $P$ in fig. 1 ) and the other with the holder taking only the established quota (I in fig. 1). The combination of these alternatives yields twelve possible scenarios for each model (fig. 1), of which only two were considered: scenario 5, the most negative, and scenario 10 , the most benign. 
escenarios solamente se tomaron en cuenta el 5, el más negativo y el 10, el más benigno.

Para calcular la biomasa con los modelos dinámicos en el caso de permiso de pesca se utilizaron los parámetros base con información de captura y esfuerzo de 1994 y se consideró una mortalidad por pesca del $20 \%$ de la biomasa como captura calculada y posteriormente restándola a la biomasa calculada para el año posterior. En todos los casos se calculó el riesgo con base en la biomasa para obtener la captura asociada a la misma.

En el caso de la pesca furtiva se sumaron los porcentajes de extracción ilegal (estimado de las encuestas, 30\% y 10\%) a la captura observada, se corrieron los nuevos valores de captura con cada modelo y se determinó la probabilidad previa para 0 , $10 \%, 20 \%$ y $30 \%$ de pesca ilegal asociada al valor de la nueva biomasa con una prueba $\mathrm{z}$, posteriormente se multiplicó por la función de verosimilitud (con los parámetros base y ambos modelos) y se dividió por la probabilidad total para obtener la probabilidad posterior de Bayes y sus capturas asociadas.

Para determinar el riesgo debido al cambio de zona se calcularon las probabilidades previas de manera similar a lo explicado anteriormente, sólo que aquí el supuesto es que, dada la incertidumbre de cambiar de área la siguiente temporada, el permisionario tiende a capturar $30 \%$ más de su cuota asignada. Estas probabilidades previas se multiplicaron por las anteriormente obtenidas.

En los casos de las temperaturas anómalas altas y bajas se consideró que estos fenómenos tuvieron una duración de dos años a partir de 1997 (Wolter y Timlin, 1997). Con respecto al efecto por variabilidad ambiental, las encuestas mencionaron que en años cálidos la calidad de la gónada de erizo disminuye porque $M$. pyrifera, el principal alimento del erizo, decae por una inhibición de nutrientes relacionada con temperaturas altas (Zimmerman y Robertson, 1985; Dean y Jacobsen, 1986). Se buscó una asociación entre las capturas anuales de $S$. franciscanus y M. pyrifera durante 1977-1993 (Molina, 1986) para Baja California, así como de éstas con la temperatura (NOAA, 1991) media anual superficial del mar de 1960-1990, con correlaciones de Pearson a un nivel de significancia del $95 \%$.

Se determinaron los niveles de biomasa asociados con temperaturas bajas $\left(<16^{\circ} \mathrm{C}\right)$, normales (entre 16 y $18^{\circ} \mathrm{C}$ ) y altas $\left(>18^{\circ} \mathrm{C}\right)$ obteniendo también sus probabilidades previas, que se multiplicaron por las dos anteriores para obtener los nuevos valores esperados de biomasa y captura con cada escenario.

En el caso de la concesión solamente se consideraron los riesgos relacionados a fenómenos naturales (temperaturas), por lo que se obtuvo la probabilidad previa asociada a la biomasa en cada rango de temperatura, después la total y, con éstas y la función de verosimilitud, la probabilidad posterior (Bayes).

La descripción completa de la simulación con modelos dinámicos, riesgos y parámetros base es:

1. Una vez obtenidos los parámetros base se determinaron los riesgos asociados a la pesquería.
To calculate biomass with the dynamic model in the case of a fishing licence, basic parameters were used taking the 1994 information on catch and effort, from the biomass for this year and using fish mortality based on an average of $20 \%$ of the biomass to consider this in the estimated catch. In all cases the risk was calculated over the biomass to obtain the catch associated with the biomass.

For fishing by poachers, the illegal fishing percentage (estimated from the poll, 30\% and 10\%) was added to the observed catch. The new catch values with each model and the prior probability for $0,10 \%, 20 \%$ and $30 \%$ of poached fish were determined, associated with the new biomass value with a $z$-test, and then multiplied by a likelihood function (with the basic parameters and both models) and divided by the total probability to obtain Bayes' posterior probability and the associated catches.

To estimate the risks associated with fishing zone reallocation, prior probabilities were calculated as the illegal fishing percentage, but we assumed that the uncertainty of fishing in the same area in subsequent seasons motivates the licence owners to increase the harvest by $30 \%$ over the established quota. These prior probabilities were multiplied by those fornmerly obtained.

We assumed that the high and low temperature anomalies lasted two years since 1997 (Wolter and Timlin, 1997). Ninety percent of those interviewed mentioned that during warm years, the sea urchin gonad quality decreases because $M$. pyrifera, the sea urchin's dominant food, decreases due to nutrient depletion related to high temperatures (Zimmerman and Robertson, 1985; Dean and Jacobsen, 1986). The association between the annual catches of $S$. franciscanus and $M$. pyrifera during 1977-1993 was made (Molina, 1986), so that the 1960-1990 mean annual sea surface temperatures (NOAA, 1991) would correspond to Pearson's correlation at $95 \%$ confidence level.

Biomass levels and prior probabilities associated with low $\left(<16^{\circ} \mathrm{C}\right)$, standard $\left(16-18^{\circ} \mathrm{C}\right)$ and high $\left(>18^{\circ} \mathrm{C}\right)$ temperatures were determined. The new levels were multiplied by the previous levels to obtain the new biomass (multiplying the prior probability with the likelihood function between total probablity) and catch expected for each scenario.

In the case of a concession, only the risks associated with natural phenomena (temperature) were considered. In this case, once the prior probability associated with biomass in each temperature range was obtained, we were able to determine the likelihood function and then the posterior probability (Bayes) could be estimated.

The full description of the simulation with the dynamic models, risks and basic parameters is:

1. Once the basic parameters were known, the risks associated with the fishery were determined.

2. The prior probability was calculated based on the risks mentioned in the polls. 
2. Se calculó la probabilidad previa con los riesgos mencionados en las encuestas.

3. Se obtuvo la función de verosimilitud con los modelos de Schaefer y de depensación crítica con parámetros base utilizando una mortalidad de $20 \%$ de la biomasa para considerarla en la captura calculada.

4. Se multiplicó la probabilidad previa de los escenarios 5 y 10 (fig. 1) por la función de verosimilitud y se dividió entre la probabilidad total.

Para comparar los escenarios 5 y 10 (fig. 1) y los derivados de concesiones con temperaturas normal, baja y alta, se calcularon los valores esperados haciendo la sumatoria de los valores obtenidos de multiplicar la probabilidad de cada escenario por la captura esperada en el mismo (Berry, 1996) de acuerdo a la siguiente ecuación:

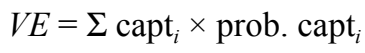

donde capt $_{i}$ es la captura calculada de cada escenario y prob. capt $_{i}$ la probabilidad de que la captura se obtenga en ese escenario particular.

\section{Resultados}

El modelo estático de depensación crítica con parámetros base (fig. 2; tablas 1 y 2) presenta dos puntos de equilibrio poblacional para el mismo nivel de esfuerzo y muestra que el tamaño de la población cambia con diferentes niveles de esfuerzo hasta llegar al esfuerzo crítico de 3500 viajes de pesca alcanzando una captura sostenible cercana a 180 t. Con parámetros provenientes de la fuente oficial, tenemos un esfuerzo crítico máximo cercano a 5000 viajes de pesca con una captura de casi 270 t y $400 \mathrm{t}$ de biomasa poblacional.

El modelo estático de Schaefer con los parámetros base muestra el nivel de esfuerzo en que ocurre un tamaño poblacional en equilibrio y muestra una relación inversa entre el esfuerzo pesquero y el tamaño de la población en equilibrio. En los 2500 viajes de pesca se alcanza la máxima captura sostenible de casi $400 \mathrm{t}$ (fig. 2, tablas 1 y 2), mientras que con los parámetros calculados a partir de una fuente oficial se encuentra casi en los 4000 viajes de pesca con cerca de $470 \mathrm{t}$ de captura.

La figura 3 muestra la biomasa calculada con el modelo de depensación crítica $\mathrm{y}$, a temperaturas altas, se observa un marcado decremento en la biomasa. El comportamiento de las curvas de captura para las predicciones de biomasas anteriores son similares y menores, con un mínimo de captura esperada menor a 200 t. Comparado con el modelo de Schaefer son muy similares e iguales para el último año.

Las biomasas (fig. 4) con temperaturas normales muestran un ligero descenso con el modelo de Schaefer y son casi constantes con el de depensación. Sus correspondientes capturas calculadas oscilan entre 400 y 500 t para ambos modelos.

En los escenarios de concesión (fig. 5) la biomasa baja al simular una temperatura alta durante dos años con ambos

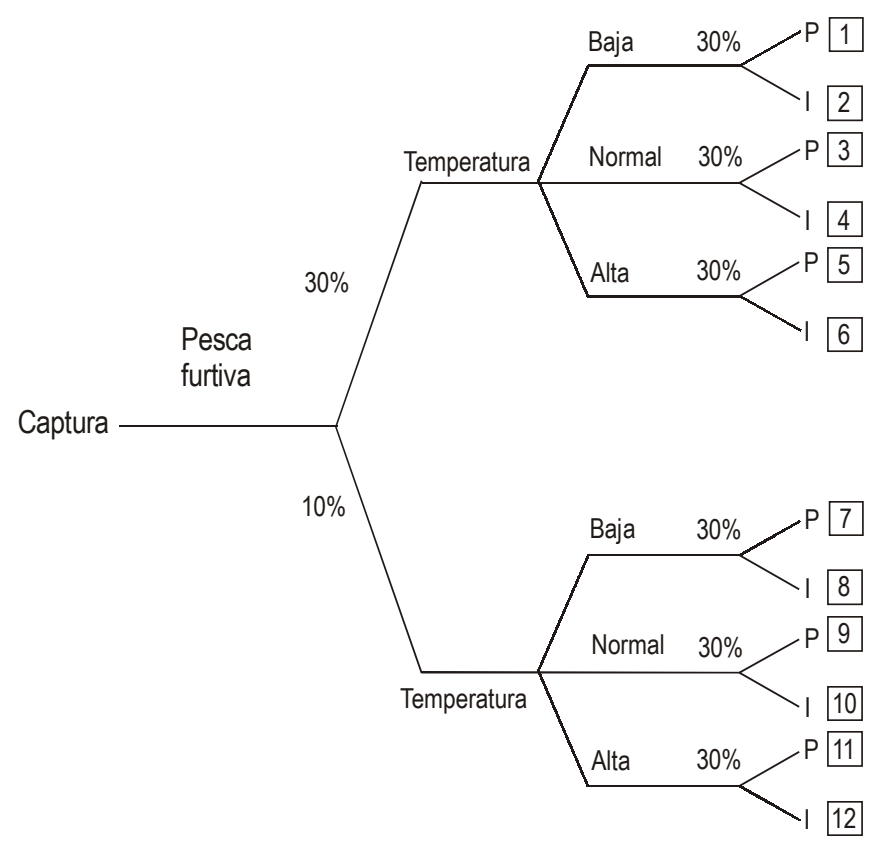

Figura 1. Escenarios pesqueros con permisos de extracción. Sobre la captura comercial se tienen dos porcentajes de pesca furtiva, $30 \%$ y $10 \%$; existen tres posibles rangos de temperatura, baja, normal y alta; y cada permisionario puede capturar $30 \%$ más de su cuota asignada $(P) 0$ limitarse a capturar ésta (I).

Figure 1. Fishery scenarios with extraction licenses. Two percentages of poachure fishing were considered over the total commercial fishing quota, $30 \%$ and $10 \%$; three possible temperature ranges, low, normal, and high; and each license holder can either overcatch $30 \%$ more $(P)$ or extract only his assigned quota (I).

3. The likelihood function was obtained with the Schaefer and critical depensation models with basic parameters considering a mortality of $20 \%$ of the biomass to calculate the estimated catch.

4. The prior probability of scenarios 5 and 10 (fig. 1) was multiplied by the likelihood function and divided by the total probability.

To compare scenarios 5 and 10 (fig. 1) and those derived from concessions with normal, high and low water temperatures, the expected values (VE) were calculated according to the catch of each scenario (Berry, 1996) using the equation:

$$
\mathrm{VE}=\Sigma \text { capt }_{i} \times \text { prob. }_{\text {capt }}
$$

where capt $_{i}$ is the catch expected from each scenario and prob. capt ${ }_{i}$ is the probability of the catch to be obtained in that particular scenario.

\section{Results}

The static critical depensation model with the basic parameters (fig. 2; tables 1,2) shows two points of population equilibrium for the same level of effort, showing that the population size changes with different levels of effort until a 
modelos, y después aquella se incrementa al normalizarse ésta. Con el modelo de depensación sus capturas son menores a 400 t, pero son poco mayores con el de Schaefer. En el escenario de una concesiones pesqueras, si la temperatura es baja durante dos años, ambos modelos siempre aumentan sus biomasas (casi 3000 t) al igual que sus capturas (casi 600 t) aunque la condición se normalice. Con temperaturas normales el comportamiento es similar pero de menor magnitud.

\section{Discusión}

Hace aproximadamente 10 años en México era difícil obtener una concesión, por lo que era necesario determinar si en términos de conservación del recurso ésta es una mejor opción de manejo que los permisos de extracción. Se eligieron los modelos descritos porque muchos investigadores utilizan el modelo de Schaefer para la pesquería del erizo rojo de mar y, debido al comportamiento particular de esta especie (efecto Allee) era necesario considerar una población crítica con el modelo de depensación para después comparar los resultados de ambas aproximaciones.

La curva de equilibrio poblacional de los modelos estáticos de depensación crítica muestra cuánto cambiará la población a diferentes niveles de esfuerzo, mostrando el nivel de esfuerzo que producirá una captura igual a la tasa de crecimiento para varios tamaños de la población $\mathrm{y}$, alternativamente, los tamaños de equilibrio poblacional que corresponderán a varios niveles de esfuerzo. Con ambos parámetros, la parte con pendiente positiva de la curva, a bajos tamaños de población, muestra una disminución de la población a la que se debe oponer otra en el esfuerzo para asegurar que el nuevo critical effort of 3500 fishing trips and a sustainable catch of nearly $180 \mathrm{t}$ are achieved. Using parameters from the official source, a critical effort of nearly 5000 fishing trips is obtained with a catch of nearly $260 \mathrm{t}$ and $400 \mathrm{t}$ of biomass.

The static Schaefer model with the basic parameters shows the level of effort at which the population is in equilibrium, and an inverse relation between effort and population size in equilibrium is apparent. Maximum sustainability is reached at 2500 fishing trips, corresponding to a maximum sustainable catch of $400 \mathrm{t}$ (fig. 2; tables 1,2), whereas using parameters from an official source the maximum sustainable yield is nearly 4000 fishing trips with $470 \mathrm{t}$ of catch.

Figure 3 shows the biomass calulated with the critical depensation model at high temperature in which a biomass decrease is observed. The lines representing catch behavior derived from previous biomass predictions are similar and smaller, with a minimum catch standard of $200 \mathrm{t}$ (at critical depensation). Compared to the Schaefer model, they are similar and the same for the last year.

The biomass predicted (fig. 4) with normal temperatures shows a slight decline using the Schaefer model and a nearly constant catch when critical depensation is considered. Their corresponding catches range from 400 to $500 \mathrm{t}$ for both models.

In the concession scenarios (fig. 5), the biomass is low when temperature is high for two years with both models, and when the situation is normal, the biomass increases. The catch is less than $400 \mathrm{t}$ with the depensation model and slightly higher with the Schaefer model. For low temperatures (over two years), both models always increase their biomass (almost
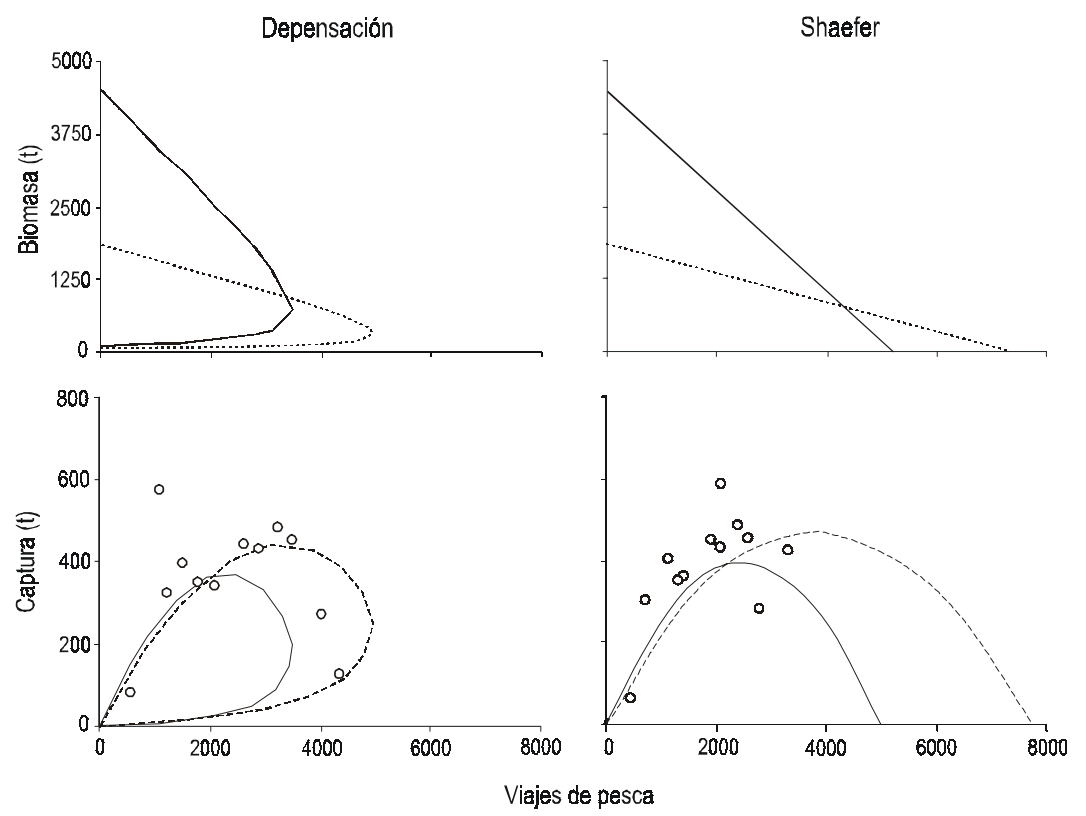

Figura 2. Curvas de equilibrio de biomasa y captura sostenible en función del esfuerzo pesquero para la zona de Santo Tomás a Punta China, Baja California (México). Parámetros base (-), parámetros calculados a partir de datos oficiales (- - -) y captura observada (o). Figure 2. Curves of equilibrium of biomass and sustainable yield in function of the fishing effort for the area from Santo Tomás to Punta China, Baja California (Mexico). Basic parameters (-), parameters estimated from an official source (- - -) and observed catch (o). 
Tabla 1. Captura calculada con los modelos estáticos de Schaefer y de depensación crítica para la zona de Santo Tomás a Punta China, Baja California (México).

Table 1. Catch estimated with the critical depensation and Schaefer static models for the area from Santo Tomás to Punta China, Baja California (Mexico).

\begin{tabular}{|c|c|c|c|c|c|c|}
\hline \multirow{3}{*}{$\begin{array}{c}\text { Esfuerzo } \\
\text { (viajes) }\end{array}$} & \multicolumn{2}{|c|}{ Schaefer } & \multicolumn{4}{|c|}{ Depensación crítica } \\
\hline & \multirow[t]{2}{*}{ De fuente oficial } & \multirow[t]{2}{*}{ Base } & \multicolumn{2}{|c|}{ De fuente oficial } & \multicolumn{2}{|c|}{ Base } \\
\hline & & & Línea superior & Línea inferior & Línea superior & Línea inferior \\
\hline 0 & 0 & 0 & 0 & 0 & 0 & 0 \\
\hline 350 & 82 & 103 & 83 & 3.3 & 102 & 3 \\
\hline 700 & 157 & 190 & 158 & 6.9 & 189 & 7 \\
\hline 1050 & 223 & 261 & 224 & 11 & 259 & 11 \\
\hline 1400 & 281 & 318 & 282 & 15.5 & 313 & 17 \\
\hline 1750 & 331 & 358 & 331 & 21 & 350 & 23 \\
\hline 2100 & 373 & 384 & 371 & 27 & 370 & 32 \\
\hline 2450 & 407 & 394 & 402 & 33 & 371 & 43 \\
\hline 2800 & 433 & 388 & 423 & 41 & 352 & 59 \\
\hline 3150 & 450 & 367 & 435 & 51 & 308 & 85 \\
\hline 3500 & 460 & 331 & 436 & 63 & 184 & 176 \\
\hline 3850 & 462 & 279 & 426 & 78 & & \\
\hline 4200 & 455 & 212 & 402 & 98 & & \\
\hline 4550 & 441 & 129 & 360 & 128 & & \\
\hline 4900 & 419 & 31 & 270 & 197 & & \\
\hline 5250 & 400 & & & & & \\
\hline 5600 & 371 & & & & & \\
\hline 5950 & 324 & & & & & \\
\hline 6300 & 285 & & & & & \\
\hline 6650 & 214 & & & & & \\
\hline 7000 & 149 & & & & & \\
\hline 7350 & 70 & & & & & \\
\hline
\end{tabular}

tamaño de la población esté en equilibrio. Esto no significa que un incremento en el esfuerzo aumente el tamaño de la población en equilibrio. Un incremento en el esfuerzo en un punto de equilibrio poblacional dado hará disminuir la población debido a que la captura será mayor que el crecimiento.

Las curvas de captura sostenible muestran dos capturas para cada nivel de esfuerzo menor a 3500 viajes (o 5000 viajes, dependiendo los parámetros), en donde solamente hay un equilibrio poblacional $\mathrm{y}$, por lo tanto, una captura sostenible (esfuerzo crítico). Por lo mismo, para niveles de esfuerzo mayores a 3500 viajes (o a 5000 viajes) no existe población en equilibrio, y de aquí que la captura sostenible sea cero.

En la porción de la curva sobre la parte de la curva de equilibrio poblacional con pendiente negativa, al incrementar el esfuerzo decrece la curva de equilibrio poblacional de manera que la captura es mayor que el crecimiento.

No se puede decir cuál de los dos modelos es mejor debido a que hay que alcanzar los límites críticos del esfuerzo para
$3000 \mathrm{t}$ ) and catch (almost $600 \mathrm{t}$ ) even though the condition is normal. With normal temperatures the behavior is similar but with lower magnitude.

\section{Discussion}

This approach was chosen because many concessions have been granted in Mexico over the past 10 years, whereas before it was difficult to get one, and it was considered important to determine whether, in terms of resource conservation, concessions are better than licences. The two models described were chosen because the Schaefer model is commonly used by researchers for the sea urchin fishery and given the particular behavior of the sea urchin (Allee effect), it was necessary to consider a critical population using a depensation model and then compare both results.

The population equilibrium curve of the static critical depensation models shows how much the population will change at different levels of effort, showing the level of effort 
compararlos y ver cómo se ajustan. Quizá ambos son buenos en la parte casi lineal de la curva superior de biomasa del de depensación crítica antes de llegar a la inflexión como en el de Schaefer ya que son muy similares sus pendientes; probablemente el primero es mejor por tener mayores consideraciones (como la población mínima viable) ya que los erizos requieren densidades mínimas en su reclutamiento (Botsford y Quinn, 1994).

Entre los factores físicos que pueden afectar la capacidad de carga de la pesquería del erizo está la disminución de alimento disponible debida a la variabilidad de temperaturas (Tegner, 1980) y a tormentas (Dayton y Tegner, 1984). Otro efecto denso-dependiente es la presencia o ausencia de erizos adultos, ya que los jóvenes utilizan las espinas de los adultos para protegerse de los depredadores y compartir su alimento.

El nivel de esfuerzo necesario para extinguir el recurso en el área de estudio, según el modelo de Schaefer y los parámetros obtenidos de la fuente oficial, es más de la mitad del esfuerzo anual medio observado. De acuerdo con el modelo logístico y los valores de los parámetros provenientes de la fuente oficial, el nivel de esfuerzo para eliminar completamente el recurso es más de la mitad del esfuerzo medio calculado para Baja California (12000 viajes de pesca). Este esfuerzo es excesivo para un área tan pequeña en relación al área total de pesca de erizo.

Cuando se determinaron los parámetros a partir de una fuente oficial solamente se contó con cuatro años de capturas y sus esfuerzos respectivos, lo cual es un período corto de tiempo para obtener parámetros poblacionales. Otra fuente de error también puede deberse a que la extracción de macroalgas se realiza durante todo el año, mientras que la de erizo rojo sólo es durante 8 meses al año.

El cálculo de los parámetros de crecimiento y sobrevivencia de los erizos jóvenes es difícil debido a que la tasa intrínseca de crecimiento poblacional es específica para su tamaño, creciendo los pequeños más lentamente (Tegner, 1989).

Si el alga a la deriva está limitada, los erizos abandonarán su hábitat escondido y ramonearán en las algas fijas (Tegner, 1989) lo cual los hace más vulnerables a la depredación.
Tabla 2. Captura y esfuerzo pesquero observado en la zona de Santo Tomás a Punta China: de 1983-1987 con base en el porcentaje de contribución de la zona a la captura estatal; de 1988-1992 de Palleiro et al. (1994); y de 1993-1994 de la Subdelegación Federal de Pesca en Baja California.

Table 2. Observed catch and effort from Santo Tomás to Punta China: for 1983-1987, using the percent contribution of the zone to the total state catch, for 1988-1992, from Palleiro et al. (1994), and for 1993-1994 from Subdelegación Federal de Pesca en Baja California).

\begin{tabular}{ccc}
\hline Año & Esfuerzo (viajes) & Captura $(\mathrm{t})$ \\
\hline 1983 & 1223 & 375 \\
1984 & 1635 & 588 \\
1985 & 224 & 88 \\
1986 & 871 & 325 \\
1987 & 2269 & 400 \\
1988 & 1500 & 356 \\
1989 & 1448 & 350 \\
1990 & 1924 & 435 \\
1991 & 2770 & 424 \\
1992 & 2680 & 479 \\
1993 & 3363 & 451 \\
1994 & 2121 & 287 \\
\hline
\end{tabular}

that will yield a catch equal to the growth rate for several population sizes and, alternatively, the equilibrium population sizes corresponding to the different levels of effort. With both parameters, the part of the curve with a positive slope at small population sizes shows a decreasing population that should be countered with a decrease in effort in order to ensure the equilibrium of the new population size. This does not mean that an increased effort will yield a higher equilibrium population level. An increased effort at a certain population equilibrium point will decrease the population because the catch will be greater than the population growth.

The sustainable catch curves show two catch levels for any fishing effort below 3500 fishing trips (or 5000 trips,
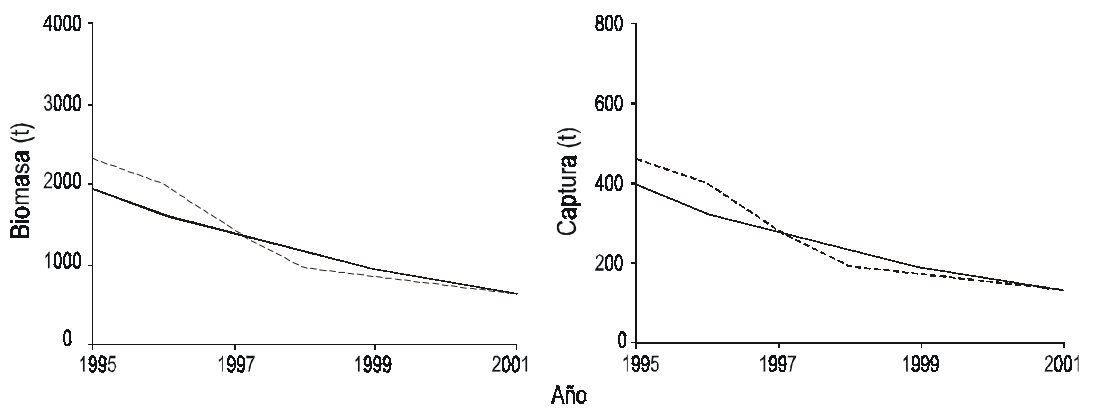

Figura 3. Biomasa y captura anual estimadas en un escenario de manejo con permisos de extracción simulando $30 \%$ de pesca furtiva, temperatura alta, y permisionarios capturando 30\% más de su cuota autorizada. Parámetros base: modelos de Depensación Crítica (-) y de Schaefer (- - -).

Figure 3. Predicted annual biomass and catch under a management scenario of extraction licences, simulating 30\% of poached fishing, high temperature, and license holders catching 30\% more than their quota. Base parameters: Critical Depensation Model (-) and Schaefer's Model (- - -). 

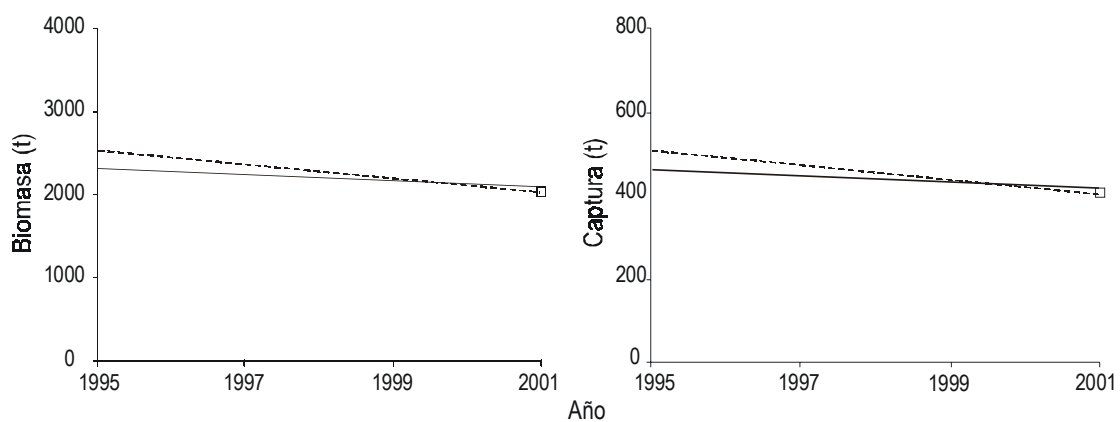

Figura 4. Biomasa y captura anual calculadas en un escenario de manejo con permisos de extracción simulando $10 \%$ de pesca furtiva, temperatura normal y permisionarios que respetan la cuota establecida. Parámetros base: depensación critica (-) y Schaefer (- - -).

Figure 4. Predicted annual biomass and catch under a management scenario of extraction licences, simulating $10 \%$ of poached fish, normal temperature, and license holders taking only their fishing quota. Base parameters: Critical Depensation Model (-) and Schaefer's Model (- - -).
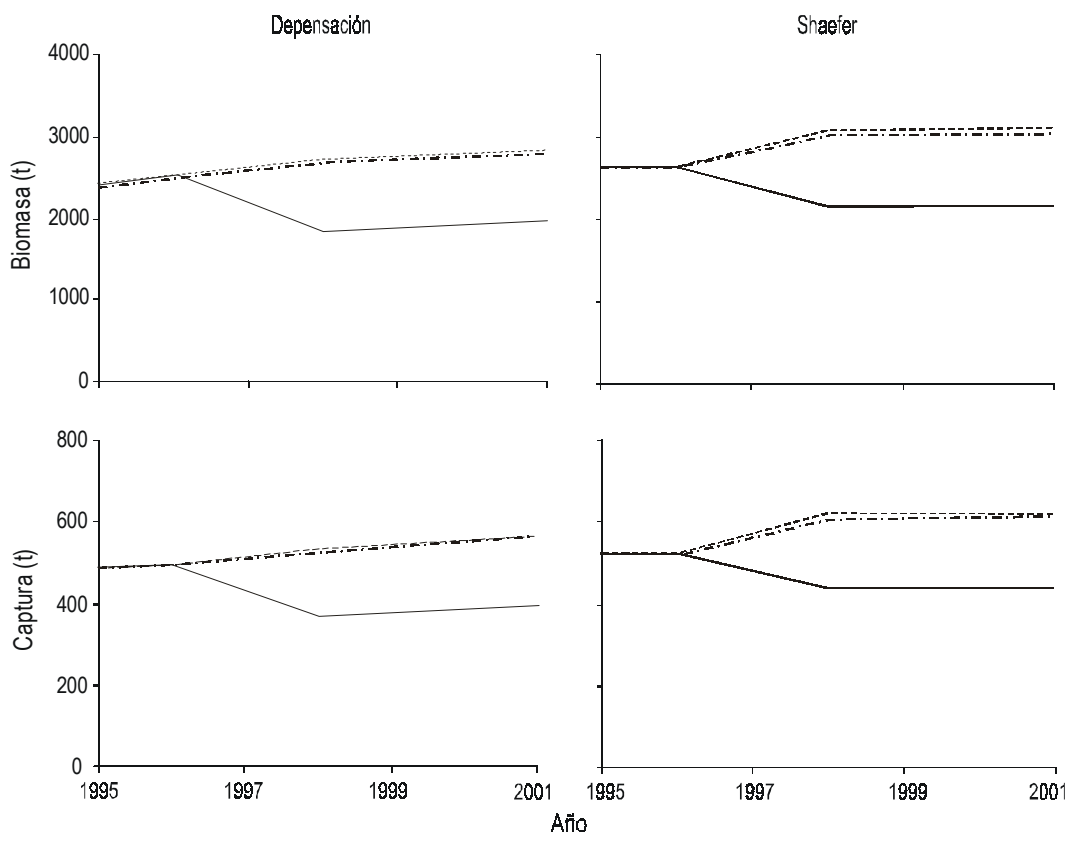

Figura 5. Biomasa y captura anual calculada bajo un escenario de manejo con concesiones de zona, con temperatura alta (-), baja (- - -), y normal (---) .

Figure 5. Predicted annual biomass and catch predicted under a management scenario of fishing zone concessions, with high $(-)$, low (-- -), and normal (---) temperatures.

Además, con el incremento de la temperatira del agua debido a El Niño, el erizo disminuye su tasas de alimentación (Kato y Schroeter, 1985). También, el tiempo de fase planctónica depende de la temperatura (Tegner, 1989).

Las simulaciones de riesgo se hicieron para seis años debido a que se consideró que la condición ambiental anómala de temperatura tardaría dos años en desaparecer, que las tasas de reclutamiento de los erizos son muy lentas durante y después de El Niño (Tegner, 1992) y que les toma de 4 a 5 años en alcanzar la talla comercial (Kato y Schroeter, 1985). Por otra parte, el promedio de vida de las embarcaciones menores utilizadas para su pesca según las encuestas es de siete años y de los motores de tres. depending on the parameters) where there is only one population equilibrium and, therefore, a single sustainable catch level (critical effort). Likewise, for effort levels higher than 3500 (or 5000) fishing trips there is no equilibrium population, hence the sustainable catch is zero.

In the part of the curve above the population equilibrium curve with negative slope, increased efforts cause the population equilibrium to decrease so that catch is greater than growth.

It is not possible to say which of the two models is better because critical limits of effort have to be reached in order to compare them and see how they fit. Perhaps both are good in the almost linear part of the upper biomass curve of the critical 
Al simular una situación anómala de temperatura alta, era de esperar que el escenario de permisos arrojara las biomasas más bajas, sin embargo llama la atención que éstas no se recuperan aún después de que la condición anómala haya terminado.

Al simular temperaturas bajas, el modelo de depensación después de los ligeros incrementos de biomasa por las bajas temperaturas, éstas tienden a descender y al igual que en los casos anteriores las probabilidades posteriores son menores que las que resultan del modelo de Schaefer. En el escenario de concesión solamente se incluyó lo relacionado con riesgos en los cambios de temperatura y como se esperaba, las temperaturas altas hacen que la biomasa disminuya más con el modelo de depensación crítica que con el de Schaefer y, en general, sus probabilidades previas y posteriores son ligeramente mayores para este último, pero con ambos modelos tiende a recuperarse. Las probabilidades previas con temperaturas bajas y normales fueron similares para ambos modelos y la tendencia es a elevar la biomasa.

Es muy difícil determinar las probabilidades previas de todos los escenarios de riesgo porque interviene la subjetividad, pero puede ser útil cuando se desea simular una situación difícilmente cuantificable, como es el efecto de la pesca furtiva y de los cambios de zona al renovar permisos. En este caso particular, es evidente (con ambos modelos y parámetros) que de manera general la biomasa de la población de erizo rojo se encuentra disminuyendo y esto habrá que tomarlo en consideración dependiendo de los eventos adversos que se prevea que puedan afectar cada temporada.

Desafortunadamente no existen trabajos similares para el erizo rojo de mar. Es importante recalcar que si no se toman medidas de manejo adecuadas para el recurso, debido a la presión que representa su alto valor comercial y su importancia económica para Baja California éste podría acabarse o disminuír drásticamente su captura.

\section{Agradecimientos}

Se agradece a los revisores anónimos, a los pescadores de Baja California que proporcionaron información, comentarios y gentilmente respondieron la encuesta. A Ellis Glazier por traducir el escrito. ERF agradece la beca otorgada por CONACYT.

\section{Referencias}

Baker, S. (1973). Growth of the red sea urchin Strongylocentrotus franciscanus (Agassiz) in two natural habitats. M.Sc. thesis, California State University, San Diego, 83 pp.

Barnes, D.R. (1977). Zoología de los Invertebrados. 3ra ed. Interamericana, México, DF, 826 pp.

Berry, A.D. (1996). Statistics. A Bayesian Perspective. Duxbury Press. Wadsworth Co., 518 pp.

Botsford, L.W. and Quinn, J.F. (1994). Spatial management of the northern California red sea urchin fishery. University of California, Davis, R/F-150, 4 pp. depensation model before the inflection point and in the Schaefer model given their very similar slopes. The former is probably better because it considers more issues (like minimum viable population), since sea urchins require a minimum density of a broodstock for successful recruitment to occur (Botsford and Quinn, 1994).

The reduced food available due to variations in temperature (Tegner, 1980) and storms (Dayton and Tegner, 1984) is one of the physical factors affecting the carrying capacity of the sea urchin fishery. Another density-dependent effect is the presence or absence of adult urchins, since their spine canopy offers juveniles protection from predators and allows them to share their food.

The level of effort needed to deplete the resource in the study area, according to the Schaefer model using parameter values from the official source, is more than half of the mean annual pressure observed. According to the logistic model and the parameter values from the official source, the level of effort to completely eliminate the resource in the area is more than half of the mean effort estimated for Baja California $(12,000$ fishing trips). This effort is excessive for such a small area in relation to the total sea urchin fishing area.

When the parameters were determined from the official source, there were only four years of catch and effort data, which is a short period for population parameters to be estimated. Another source of error can be that whereas macroalgae are harvested throughout the year, sea urchins are fished only eight months a year.

The estimation of the growth and survival parameters for young sea urchins is difficult because the intrinsic growth population rate is size-specific, small sea urchins growing more slowly (Tegner, 1989).

The possible effects of the condition of the macroalgae on the sea urchin populations is determined by whether the drifting algae are limited and the sea urchins have to leave their protected habitat and start grazing on fixed algae (Tegner, 1989). Furthermore, the increased seawater temperature resulting from El Niño, causes sea urchins to decrease their feeding rates (Kato and Schroeter, 1985). The length of time they remain planktonic depends upon the temperature (Tegner, 1989).

The risk simulations were calculated for six years considering that the anomalous sea surface temperature (high or low) would take two years to disappear, that the recruitment rates of the sea urchin are slow during and after El Niño (Tegner, 1992), and that sea urchins take 4-5 years to reach commercial size (Kato and Schroeter, 1985). On the other hand, according to the polls, the average useful life span of the fishing boats is seven years and that of the engines, three years.

In the simulation, anomalous high temperatures in the licence scenarios were expected to yield lower biomasses; however, it is worth noting that the biomass does not recover once the anomalous condition has ended.

With low temperatures and the critical depensation model, the resulting biomass, after a slight increase, tends to decrease 
Botsford, L.W., Quinn, J.F., Wing S.R. and Brittnacher, J.G. (1993). Rotating spatial harvest of a benthic invertebrate, the red sea urchin, Strongylocentrotus franciscanus. Proceedings of the International Symposium on Management Strategies of Exploited Fish Populations. Alaska Sea Grant College Program, AK-SG-9302. pp. 409-428.

Clark, C.W. (1976). Mathematical Bioeconomics. John Wiley, 352 pp.

Dayton, P.K. and Tegner, M. (1984). Catastrophic storms, El Niño, and patch stability in a southern California kelp community. Science, 224(4646): 283-285.

Dean, T.A. and Jacobsen, F.R. (1986). Nutrient limited growth of juvenile kelp, Macrocystis pyrifera, during the 1982-1984 "El Niño" in southern California. Mar. Biol., 90: 597-601.

Haaker, P. (1992). The southern California red sea urchin: A case history. The management and enhancement of sea urchins and other kelp bed resources: A Pacific rim perspective publication. TCSGCP-028. California Sea Grant College, University of California, pp. 1-43.

Halman, P. and Rudie, D. (1992). The southern California red sea urchin fishery, 1972-1992. The management and enhancement of sea urchins and other kelp bed resources: A Pacific rim perspective publication. T-CSGCP-028. California Sea Grant College, University of California, pp. 1-43.

Hilborn, R. and Walters, C.J. (1992). Quantitative Fisheries Stock Assessment: Choice, Dynamics and Uncertainty. Chapman and Hall, New York, 570 pp.

Holling, C.S. (1959). The components of predation as revealed by a study of small-mammal predation of the European pine sawfly. Can. Entomol., XCI: 293-320.

Jamieson, G.S. and Caddy, J.F. (1986). Research advice and its application to management of invertebrate resources: An overview. In: G.S. Jamieson and N. Bourne (eds.), North Pacific Workshop on Stock Assessment and Management of Invertebrates. Can. Spec. Publ. Fish. Aquat. Sci., pp. 416-424.

Kato, S. and Schroeter, S.C. (1985). Biology of the red sea urchin, Strongylocentrotus franciscanus, and its fishery in California. Mar. Fish. Rev., 47(3), 1-19.

Ley de Pesca y su Reglamento (1999). Secretaría de Medio Ambiente, Recursos Naturales y Pesca. México, DF, 113 pp.

Malagrino-Lumare, G. (1972). Extracción y preservación de las gónadas de erizo. Tesis de licenciatura, Univerisdad Autónoma de Baja California, Ensenada, México, 79 pp.

Molina, M.J. (1986). Notas sobre tres especies de algas marinas: Macrocystis pyrifera, Gelidium robustum y Gigartina canaliculata de interés comercial en la costa occidental de Baja California, México. Contribuciones Biológicas y TecnológicoPesqueras. SEPESCA, Instituto Nacional de la Pesca. Ensenada, BC. Doc. Téc. No. 3, 39 pp.

Mottet, M.C. (1976). The fishery biology of the sea urchin in the family Strongylocentrotidae. Washington Dept. Fish. Tech. Rep., No. 20, 66 pp.

Neave, F. (1953). Principles affecting the size of pink and chum salmon populations in British Columbia. J. Fish. Res. Board Can., 9(9): 450-491.

NOAA (1991). CD-ROMs NODC-02 and NODC-03: Global ocean temperature and salinity profiles. US Dept. Commerce, Washington, DC, Informal Rep. No. 12.

Palleiro, J. (1982). Estimación de la densidad y crecimiento del erizo rojo Strongylocentrotus franciscanus (Agassiz) para la zona de Santo Tomás, Baja California, México. Tesis de licenciatura, Univerisdad Autónoma de Baja California, Ensenada, México, $68 \mathrm{pp}$.

Palleiro, J. (1987). Biología del erizo rojo Strongylocentrotus franciscanus y su pesquería en Baja California. Proyecto: Erizo de Mar. Instituto Nacional de la Pesca, Centro Regional de and, as in the preceding cases, posterior probabilities are lower than those resulting from the Schaefer model. In the simulations with concessions, only risks associated with changes in temperature were included and, as expected, high temperatures cause the biomass to decrease in greater proportion using the critical depensation model than with the logistic model. The prior and posterior probabilities are higher for the logistic than for the depensation model. For low and normal temperatures, prior probabilities were similar with both models and biomass tends to increase over time.

The determination of previous probabilities for all possible scenarios is difficult because subjectivity intervenes, but it can still be useful when one wishes to simulate a situation that is difficult to quantify, such as the effect of poaching and zoning changes upon licence renewal. Using both models and different parameters, the biomass of the red sea urchin population is found to be low and harmful events that can occur at any time should be considered.

Unfortunately there are no similar studies for the red sea urchin. It is worth noting that if appropriate management measures are not adopted for this economically important species in Baja California, the red sea urchin fishery could be depleted or drastically reduced.

\section{Acknowledgements}

We thank the anonymous reviewers for their comments, the Baja Californian fishermen who took part in the polls and Ellis Glazier for editing the English-language text. ERF thanks CONACYT for the scholarship granted.

English translation by the authors.

Investigaciones Pesqueras de Ensenada. Documento Interno, $19 \mathrm{pp}$.

Palleiro, J., Aguilar, D. y Navarrete, M. (1994). Cambios en la densidad de población de erizo rojo Strongylocentrotus franciscanus, en un área sujeta a explotación comercial, Santo Tomás, BC. Instituto Nacional de la Pesca, Centro Regional de Investigación Pesquera de Ensenada. Documento Interno, 17 pp.

Peterman, R.M. (1977). A simple mechanism that causes collapsing stability regions in exploited salmon populations. J. Fish. Res. Board Can., 34: 1130-1142.

Ricker, W.E. (1954). Stock and recruitment. J. Fish. Res. Board Can., 11(5): 559-623.

Romero, J. and Bertsch, H. (1984). Efectos de la pesquería del erizo rojo, Strongylocentrotus franciscanus (Echinordermata), sobre la estructura de su población en Santo Tomás, Baja California, México, con una comparación de métodos de muestreo. Cienc. Mar., 10(2): 85-95.

Sóbol, I.M. (1983). Método de Montecarlo. Ed. MIR, Moscow, 79 pp.

Tegner, M.J. (1980). Multispecies considerations of resource management in southern California kelp beds. Can. Tech. Rep. Fish. Aquat. Sci., No. 954: 125-143.

Tegner, M.J. (1989). The feasibility of enhancing red sea urchin, Strongylocentrotus franciscanus, stocks in California: An analysis of the options. Mar. Fish. Rev., 51(2): 1-22. 
Tegner, M.J. (1992). Red urchin recruitment patterns in southern California. In: The Management and Enhancement of Sea Urchins and Other Kelp Bed Resources: A Pacific Rim Perspective. Calif. Sea Grant. Rep. No. T-CSGCP-028, 43 pp.

Tegner, M.J. and Dayton, P.K. (1981). Population structure, recruitment and mortality of two sea urchins: Strongylocentrotus franciscanus and $S$. purpuratus, in a kelp forest near San Diego, California. Mar. Ecol. Prog. Ser., 5: 255-268.
Wolter, K. and Timlin, M. (1997). Multivariate ENSO index for the six strongest historic El Niño events vs. the current event. NOAA-CIRES. Climate Diagnostics Center, University of Colorado at Boulder, USA. Internet (www.srh.noaa.gob/lch/ research/BPTLCH.HTM).

Zimmerman, R.C. and Robertson, D.L. (1985). Effects of El Niño on local hydrography and growth of the giant kelp, Macrocystis pyrifera, at Santa Catalina Islands, California. Limnol. Oceanogr., 30(6): 1298-1302. 